the most reliable and best technique is to determine the presence of C.P.P.D. by $x$-ray diffraction. This method can be used even when only microscopic specimens of the material are available.

Calcification of the meniscus in the knee is very common in chondrocalcinosis. In the roentgenological examination of such cases various projections should be tried in order to visualize also calcifications of the joint cartilage, which are of greater significance in the diagnosis of chondrocalcinosis. The synovial fluid (joint effusion) has been described as milky and was of such appearance in one of our cases at Ljungby.

In their series of 33 cases D. Žitnan and S. Sitàj ${ }^{1}$ found five pedigrees with 24 cases, and they regard chondrocalcinosis as hereditary, as it affects a greater number of members of one family, passing from generation to generation. It is true that of 80 cases McCarty found only two crystallographically proved examples of familial disease, but three other "definite" cases had asymptomatic siblings with typical calcifications on roentgenograms and many others gave histories suggestive of the disease in close relatives. Several other authors have found a familia occurrence of the disease. Perhaps about 60 familial cases are described in the literature. At the department of internal medicine, Lasarettet, Ljungby, we found the disease (with $x$-ray diffraction) in 4 of 12 siblings. Familial investigations are of particular interest in chondrocalcinosis, but are difficul because the disease does not seem to become manifest before the age of 20 years, and because in long-standing cases arthritic alterations predominate and are accompanied by a gradual loss of calcified cartilage, which makes a roentgenological diagnosis difficult. In the investigation of the mode of inheritance it is also important to find out how many members of a family or of a sibship are not affected or not carriers of the gene for the disease.-I am, etc. CURT W. Ekelund.

Department of Medicine Lasarettet, Ljungby, Sweden. REFERENCES

Zitnan. D., and Sitaj, S., Acta Pistiniana, 1966, $2,20$.

de Sèze, S., Ryckewaert, A., Hubault, A., Kahn Kahn, M.-F Mitrovic, D. and Solnica, J. Sem. Hôp. Paris, 1966, 42, 2461.

7 th ed., p., 113, ed. J. L. Hollander, 1966. Philadelphia.

- Currey, H. L. F., Kay, J. J., Mason, R. M., and Swettenham, K. V., Ann. rheum. Dis., 1966,
25, 295.

\section{Epidemic of Glandular Fever}

SIR,-We wish to report an epidemic of glandular fever in a rural practice of 3,000 patients covering some 24 villages over an area of 34 square miles ( $86 \mathrm{sq} . \mathrm{km}$.).

Of the 75 patients with this clinical diagnosis, 54 have had positive Paul-Bunnell tests as well as the characteristic abnormal monocytes, while 21 have so far been Paul-Bunnell negative. More cases are still coming to light. 13 families have had two or more cases and six have had three or four members involved. We think that these patients who are Paul-Bunnell negative have, in fact, got glandular fever and not toxoplasmosis or one of the other conditions with which it may be confused. This is because other members of the familv with the same clinical picture and blood film appearances have been Paul-Bunnell positive at some stage in their illness.
One of the presentations, which we have not seen described elsewhere, is as an acute psychiatric disorder: five of our series presented thus, and were only subsequently diagnosed as glandular fever. Of these, two had acute schizophrenia and three acute depression with suicidal tendencies. We would suggest that if more haematological studies were done on patients with glandular feverlike clinical states then the incidence of the disease might be seen to be well above the figure of 38 per 100,000 population found by Penman.

We are grateful to the pathology department of King's Lynn General Hospital for performing all the tests on our patients.

$\begin{array}{lc}\text {-We are, etc., } & \text { MichaEl KLABER. } \\ \begin{array}{c}\text { King's Lynn, } \\ \text { Norfolk. }\end{array} & \text { JEAN LACEY. } \\ & \text { ReferenCB } \\ \text { 1 Penman, H. G., f. Hyg. (Lond.), 1966, 64, 45 }\end{array}$

\section{Magnesium and Mania}

SIR,-Chronic mania is uncommon, and in modern psychiatric practice laboratory investigation is unlikely to include a magnesium serum analysis. Persistently disturbed and violent patients can now be treated effectively with phenothiazines, of which chlorpromazine is the most reliable.

The hypothesis that there may be a link between chronic mania and hypomagnesaemia has yet to be tested, but, since Dr. J. R. Govan and others (4 May, p. 278) have reemphasized the twofold action of magnesium as a central depressant and as a block to the transmission of neuromuscular impulses, it may be useful to record some unpublished work (Horsley, 1937) on the use of intravenous magnesium sulphate in chronic mania.

A woman of 45 had suffered for many years from chronic mania complicated by periodic bouts of homicidal violence. The powerful sedatives in common use in 1937 were quite ineffective, and so an attempt was made to reduce the furore by the slow intravenous injection of a $10 \%$ solution of magnesium sulphate. During the injection the patient relaxed and, with slurred speech, she described subjective sensations of tingling, generalized flushing, and lethargy. The next day the patient was still subdued but fit to resume her usual occupation as the ward's best scrubber. Some months later, in another outburst of violence, similar treatment was again effective.-I am, etc.,

\section{Kings Langley, J. StePheN HoRsley.
Herts.}

\section{Overcrowding in Psychiatric Hospitals}

SIR,-Dr. C. Entwistle's conclusion (8 June, p. 626) that national adoption of "techniques ... employed at Rubery Hill Hospital would save the National Health Service hundreds of millions of pounds" is speculative. He suggests we have chosen inappropriate techniques to treat our patients, but our scheme ${ }^{12}$ was merely a preliminary assessment of long-stay patients on our firm. This had not been previously attempted, but as a result of it we are convinced we have very few chronic patients left who could be discharged unless unexpected increases occur in local authority of community aftercare services in this area. Although therapeutic community benefits are widely acknowledged, it has still to be proved that group methods are superior to intensive individual psychotherapy, chemotherapy, physical, or other methods of treatment for chronic psychiatric patients, particularly in the elderly category. Most of the patients we interviewed were severely institutionalized and had been in hospital for periods exceeding 30 years.

"Revolving doors" are largely contingent upon the recurrent illnesses we are obliged to treat, although they are certainly preferable to closed ones. Precipitate discharge of chronic patients from one mental hospital can readily lead to overcrowding in neighbouring hospitals, particularly in densely populated urban areas and if adequate aftercare is not developed. The findings from our recent review suggest that our hospital will remain the permanent home for many of our chronic and elderly patients. We are privileged to make their stay here as comfortable and enjoyable as possible, which means, among many other things, doing away completely with all locked wards. But we are still overcrowded, despite transfer of more than 60 patients to surrounding hospitals following recent difficulties. Criteria for admission to the psychiatric hospital need to be far more selective. Patients who are not mentally ill should never have to be admitted to mental hospitals merely because there are no beds for them elsewhere. The late Dr. H. B. Kidd, of the Towers Hospital, Leicester, emphasized that many wrongly placed patients tend to vegetate and deteriorate rapidly. Furthermore, unless there is far greater reciprocity between all the psychiatric services overcrowding will increase and new chronics will emerge, thereby perpetuating the vicious circle. For instance, as a first step I would welcome smoother and swifter exchange of patients from the psychiatric hospital to local authority welfare accommodation.-I am, etc.,

$$
\begin{aligned}
& \text { Shelton Hospital, } \\
& \text { Shrewsbury, Shropshire. }
\end{aligned}
$$

\section{REFERENCES}

Barker, J. C., and Miller, M., Nursing Mirror, 1968, 126. No. $7,21$.

Barker, J. C., and Miller, M., Midland Medical Review. In press.

\section{Deputizing Services and Practitioners' Liability}

SIR,-With reference to the letter from the Secretaries of the Medical Defence Union and Medical Protection Societies (22 June, p. 765) regarding the indemnification of subscribers to a deputizing service against errors and omissions of administrative staff, may I clarify the situation so that all deputizing services are not tarred with the same brush ?

Many services, this one included, indemnify the user of the service against action brought against him arising from the negligence or default of any of the Service employees, including lay and administrative employees. The sums vary from $£ 100,000$ to $£ 250,000$ for any one specific incident.

Users of a deputizing service should make inquiry to ensure that they are indemnified and would be advised not to use a service which does not provide such indemnification. -I am, etc.,

Liverpool $6 . \quad$ Medical Director, 